\title{
Retrospective study of quantitative free light chain levels in random urine of patients with multiple myeloma
}

\author{
J ozef Malysz, J unjia Zhu, Michael H. Creer, Nathan G. Dolloff, Michael G. Bayerl, Giampaolo \\ Talamo
}

Division of Hematology and Oncology, Department of Anatomic \& Clinical Pathology and Hematopathology, Penn State Milton S. Hershey Medical Center, Penn State Hershey Cancer Institute, 500 University Drive, Hershey, PA 17033, U.S.A.

Correspondence: J ozef Malysz. Address: Department of Anatomic \& Clinical Pathology and Hematopathology, Penn State Milton S. Hershey Medical Center, Mail Code H179, 500 University Drive, Hershey, PA 17033-0850, U.S.A.

Email: jmalysz@hmc.psu.edu

Received: March 29, 2013

Accepted: August 1, 2013

Online Published: August 15, 2013

DOI : $10.5430 /$ jhm.v3n2p8

URL: http://dx.doi.org/10.5430/jhm.v3n2p8

\section{Abstract}

The traditional method to quantify the immunoglobulin free light chains (FLCs) in patients with multiple myeloma (MM) is based on either their serum levels or on 24-hour urine collections. The latter method is cumbersome and often inaccurate, and serum levels are currently the preferred method for quantifying FLCs in MM. Scarce data exist on the FLC quantification in random urine samples. In this study, we first compared serum and urine levels of FLCs measured in 24-hour specimens obtained from 56 consecutive MM patients. We subsequently examined the same correlation in 209 random urine specimens obtained from a second cohort of 117 consecutive MM patients. Serum FLCs were highly correlated, both with the 24-hour and the random urine specimens. With the latter, the Pearson coefficient $r$ was 0.805 and 0.748 for kappa and lambda light chains, respectively $(p<0.001)$, even in the presence of renal insufficiency. Random urine FLCs levels $>1.2 \mathrm{mg} / \mathrm{dL}$ predicted a positive urine immunofixation with a specificity and sensitivity of $52.7 \%$ and $95.8 \%$, respectively. Since random urine quantification of kappa and lambda FLCs paralleled their serum counterparts over time, this method could represent an additional non-invasive test for assessing disease activity in MM patients.

\section{Key words}

Serum free light chains, Urine light chains, Bence-Jones proteins, Monoclonal immunoglobulins, Multiple myeloma

\section{I ntroduction}

Multiple myeloma (MM) is a malignant hematologic neoplasm characterized by the proliferation of monoclonal plasma cells involving the bone marrow. The cell of origin is a post-germinal center cell of B lineage, expressing restricted immunoglobulin light chain and one of postswitch isotypes of heavy chain (IgH), presumably escaping NK cell surveillance ${ }^{[1,2]}$. With the exception of rare nonsecretory cases, all MM plasma cells produce and secrete monoclonal immunoglobulins, which can be found in the serum and urine. These monoclonal immunoglobulins may consist of an entire antibody with heavy chains (most commonly IgG, $\operatorname{IgA}$, and $\operatorname{IgD}$ ) and light chains (kappa or lambda), or only light chains ${ }^{[3]}$. All these molecules can be measured in the serum and/or urine and serve as tumor biomarkers. In fact, the 
International Uniform Response Criteria require the quantification of the monoclonal immunoglobulins, both at the time of diagnosis and periodically during follow-up of $\mathrm{MM}$, in order to assess response to treatment and monitor disease activity ${ }^{[4]}$. The entire immunoglobulin molecules can be measured directly in the serum, and the monoclonal component ("M spike") quantified by serum protein electrophoresis (SPEP) or capillary zone electrophoresis (CZE). The kappa and lambda light chains not associated with immunoglobulin heavy chains can be quantified in the serum or urine with the "free light chain" (FLC) assay, which was introduced in the last decade ${ }^{[5-8]}$. In the routine clinical practice, this test has often replaced the quantification of the urine M spike obtained with the traditional 24-hour urine collection.

Although the role of serum FLCs is well established ${ }^{[9-11]}$, the use of FLCs in urine specimens remains controversial, and it is not routinely adopted for the diagnosis and follow-up of MM patients ${ }^{[12]}$. In this study, we tested the correlation of the FLC in a 24-hour and random urine collections with their matched serum FLC levels. Since FLCs are known to increase in the setting of renal insufficiency ${ }^{[13]}$, we also conducted a multivariate analysis which included patients' glomerular filtration rate (GFR).

\section{Patients and methods}

After obtaining permission from our institutional review board, we retrospectively examined 117 consecutive MM patients seen at the Myeloma Clinic of the Penn State Hershey Cancer Institute in 2010. Laboratory tests with monoclonal immunoglobulins both in serum and urine were routinely obtained by the treating physician during the clinical follow-up of those patients. We conducted a correlation analysis of the quantitative measurement of urine and serum kappa and lambda FLC obtained on the same day, both in patients with normal renal function and in patients with renal insufficiency. Urine FLC ( $\mathrm{uFLC}$ ) analysis was initially performed in specimens obtained from 24 hour urine collections by Quest Diagnostic Nichols Institute (14225 Newbrook Drive, Chantilly, VA 20153) (56 patients). The provided normal reference range of urine FLCs was $0.13-2.41$ and $0.02-0.67 \mathrm{mg} / \mathrm{dL}$ for kappa and lambda, respectively. We subsequently performed the same test in random urine specimens from other 117 consecutive MM patients. The uFLC test was performed by immunonephelometry on the SPAPLUS automated nephelometric analyzer using commercially available reagents from "The Binding Site", Inc. (San Diego, CA).

The linear correlation between urine and serum kappa and lambda FLCs was examined by a bivariate correlation study and numerically measured by Pearson correlation coefficient $(r)$. Both urine and serum data were log-transformed to make sure the related statistical assumptions (linearity, normality, and equal variances assumptions) were satisfied. The above correlations were re-examined using multivariate linear mixed effect models with repeated measures (since each patient could have multiple measurements over time) by controlling the GFR. This was estimated from their plasma or serum creatinine concentration based on the equation derived from the Modification of Diet in Renal Disease Study Group ${ }^{[14]}$. In addition, receiver operating characteristic (ROC) analysis was performed to evaluate the performance of random urine FLC levels in predicting a positive urine immunofixation (UIFE). Sensitivity and specificity analysis was done to determine an optimal threshold for the prediction. Data analysis was done using SAS ${ }^{\circledR}$ statistical software (Version 9.2, SAS Institute Inc., Cary, NC) and R script language (Version 2.15.2, The R Foundation). The significance level was set at 0.05 .

\section{Results}

Comparison of serum and 24-hour urine FLCs in a cohort of $56 \mathrm{MM}$ patients provided a Pearson coefficient of 0.801 $\left(\mathrm{r}^{2}=0.64\right)(p<0.001)$. The scatterplot of the log-transformed values is shown in Figure 1. The regression equation obtained from the analysis was: urine FLC $=55+2.06$ x serum FLC (expressed as $\mathrm{mg} / \mathrm{dL}$ ), or on the log-scale as: $\log$ urine FLC $=$ $0.46+0.84 \times \log$ serum FLC. We subsequently applied the same analysis in 209 random urine samples obtained from other $117 \mathrm{MM}$ patients. Fifty nine patients were males (median age, 65 years; range, $42-86$ years) and 58 were females 
(median age, 65.5 years; range, 49-81 years). The monoclonal immunoglobulin types were IgG-kappa ( $\mathrm{n}=41$ ), IgG-lambda $(\mathrm{n}=22)$, kappa light chain only $(\mathrm{n}=16)$, IgA-kappa $(\mathrm{n}=14)$, IgA-lambda $(\mathrm{n}=12)$, lambda light chain only $(\mathrm{n}=6)$, IgD-lambda $(\mathrm{n}=2)$, IgD-kappa $(\mathrm{n}=1)$, and IgE-kappa $(\mathrm{n}=1)$. Two patients with nonsecretory MM were excluded from the analysis. Median urine free kappa and lambda concentrations were 39.9 (range, 1.13-22,200 mg/dL) and 4.53 (range, 0.05-85,500 $\mathrm{mg} / \mathrm{dL}$ ), respectively. Median serum free kappa and lambda concentrations were 1.58 (range 0.02-952) and 1.36 (range $0.03-5,030$ ), respectively. We found a significant correlation between random urine and serum FLC, both for kappa and lambda proteins, with a Pearson correlation coefficient $(\mathrm{r})$ of $0.805(p<0.001)$ and $0.748(p<0.001)$ for kappa and lambda light chains, respectively (see Figure 2A). The above correlation values were re-examined using normalized values (i.e. the serum/urine free light chain concentrations were normalized by serum/urine creatinine values, resulting units of $\mathrm{mg}$ FLC per gram creatinine). We observed a statistically significant correlation: $\mathrm{r}=0.726(p<0.0001)$ and $\mathrm{r}=0.587(p<0.0001)$ for kappa and lambda light chains, respectively (see Figure 2B), after controlling for GFR. Such correlation remained significant in a multivariate regression analysis (see Table 1-1), both in patients with normal renal function and in patients with renal insufficiency, defined by GFR $\leq 60 \mathrm{~mL} / \mathrm{min}$ (see Table 1-2). Random urine quantification for kappa and lambda light chains paralleled their serum counterparts over time in all patients (data not shown). Results from 5 representative patients are shown in Figure 3. In some cases, at the time of MM relapse, uFLCs increased earlier and showed higher levels than their serum counterparts (as in patient B of Figure 3).

Figure 1. Correlation between serum and urine free light chains in 24-hour urine samples from 56 consecutive myeloma patients. Both serum and urine free light chain measurements were expressed in units of $\mathrm{mg} / \mathrm{dL}$ before $\log$ transformation.

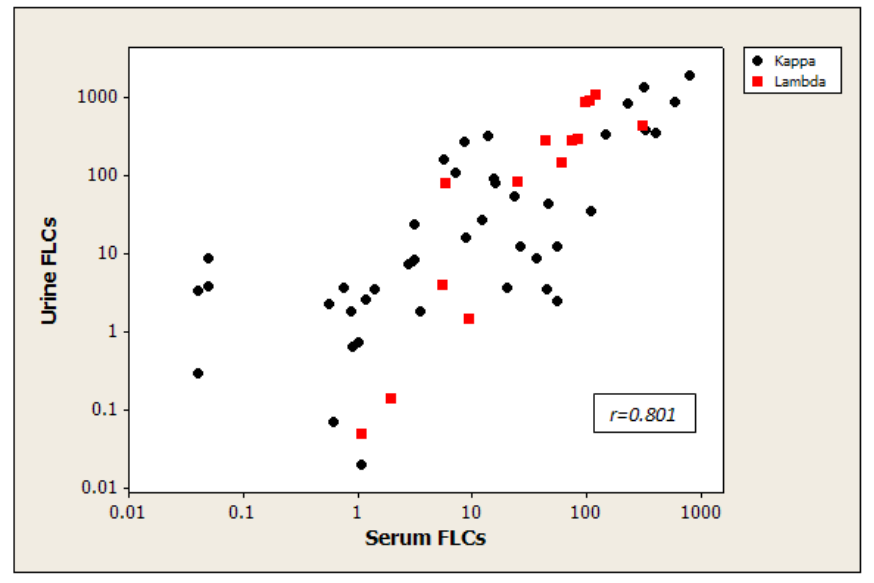

Urine vs. Serum measures: Kappa Pearson Correlation $=0.805$

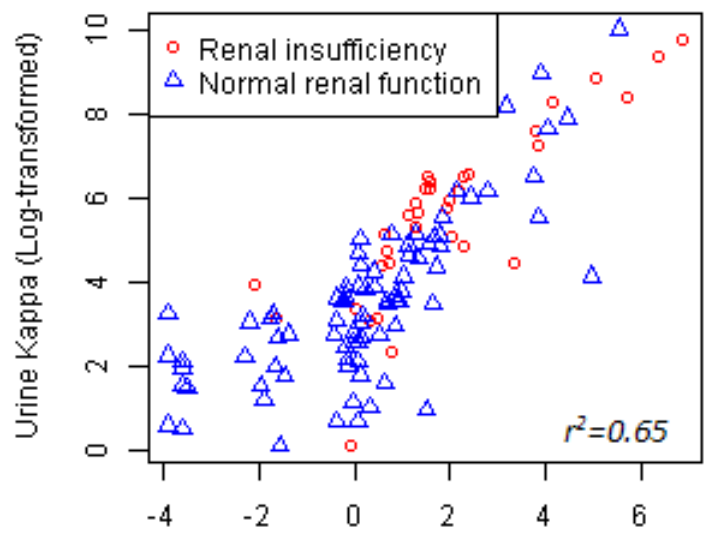

Serum Kappa (Log-transformed)
Urine vs. Serum measures: Lambda Pearson Correlation $=0.748$

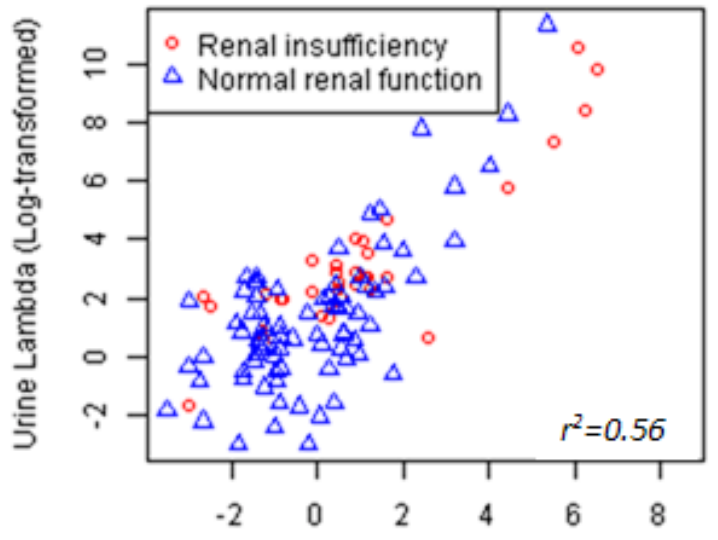

Serum Lambda (Log-transformed)

Figure 2A. Correlation between serum and random urine free light chains in 209 samples from 117 myeloma patients; both serum and urine free light chain measurements were expressed in units of $\mathrm{mg} / \mathrm{dL}$ before log transformation 


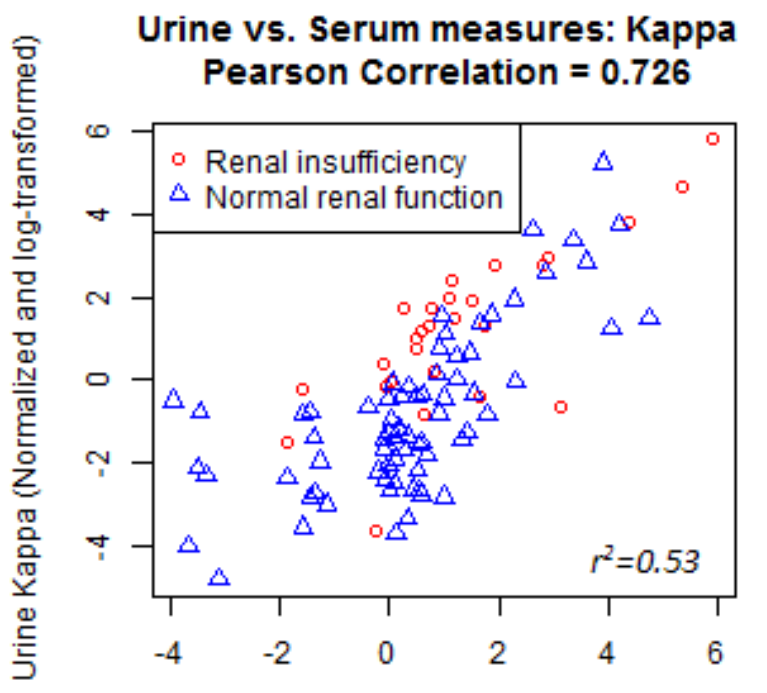

Serum Kappa (Normalized and log-transformed)

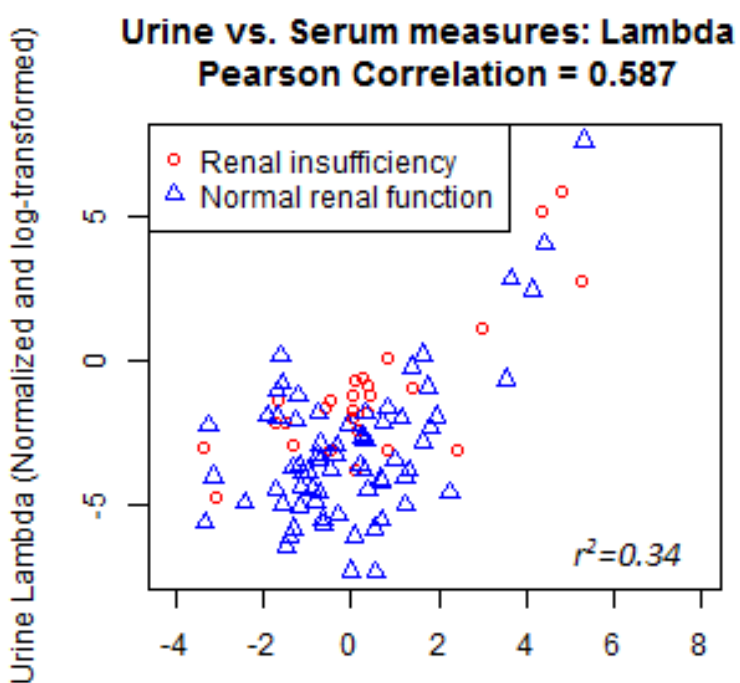

Serum Lambda (Normalized and log-transformed)

Figure 2B. Correlation between the normalized serum and random urine free light chains; data log-transformed

We compared the levels of random uFLCs with the results of the uIFE determined at the same time (expressed as either "negative" or "positive"), and we found a highly significant difference $(p<0.0001)$. Figure 4 shows the ROC curve of the performance of kappa or lambda FLCs as a binary classifier for the uIFE. The area under the curve (AUC) of 0.874 indicates a good separation of positive vs negative uIFE by the uFLCs measures. The threshold of 0.2 on log-scale, which corresponds to the original scale of $1.2 \mathrm{mg} / \mathrm{dL}$, leads to a specificity and sensitivity of $52.7 \%$ and $95.8 \%$, respectively.

\section{Discussion}

The traditional methods to measure the kappa and lambda light chains produced by MM cells are the serum FLC assay and the quantification of the urine M spike obtained with a 24-hour urine collection. The latter method is problematic both for patients and physicians. Patients usually find it cumbersome to collect all urine excreted in a day, and several studies have confirmed high rate of inaccurate collections ${ }^{[15-17]}$. In one report, more than $20 \%$ of the 24 -hour samples were discarded as a result of incomplete collection, and difficulties associated with obtaining proper samples often led to unreliable results ${ }^{[18,19]}$. Moreover, laboratory manipulation of 24-hour specimens is costly and time consuming ${ }^{[20-22]}$. Our group has previously reported that the use of the random ("spot") protein/creatinine ratio is a valid alternative in estimating the daily proteinuria in MM patients ${ }^{[23]}$, but this test cannot be used as a tumor biomarker, because it measures all proteins present in the urine, not only the monoclonal immunoglobulin compartment.

Our study demonstrates a significant level of correlation between serum FLCs and FLCs in the random urine of MM patients. While other groups have previously compared serum FLCs with the FLCs in the 24-hour urine ${ }^{\text {[24] }}$, we performed similar analysis in spot urine samples obtained at random time points. Comparing FLC concentrations in urine and serum (see Figure 2), uFLC concentrations were significantly higher, suggesting that measurement of uFLC can be a more sensitive marker for detection of residual disease in patients following treatment. Because of the high sensitivity of the test, a normal result can be reassuring for both patients and physicians. The FLC measurement in the random urine may be a valuable alternative to the cumbersome 24-hour urine collection routinely obtained for monitoring the disease activity, because we observed parallel variation of FLC in serum and urine spot samples, as illustrated in 5 representative cases shown in Figure 3. Therefore, FLC quantitation in the random urine could be a reliable, noninvasive, and certainly more convenient method in adjunct to serum FLC and SPEP in the assessment of disease activity of MM patients. Although we cannot recommend the routine use of FLC quantification in random urine of MM patients at the present time, we recognize 
that a spot urine sample is easy to obtain, and it could be proposed as a simpler method to assess disease activity during their clinical follow-up. In addition, it is noninvasive, and as such can decrease patients' anxiety associated with frequent needle sticks for blood draws as well as the rate of needle stick injuries including hemorrhage, hematomas and infections.

A

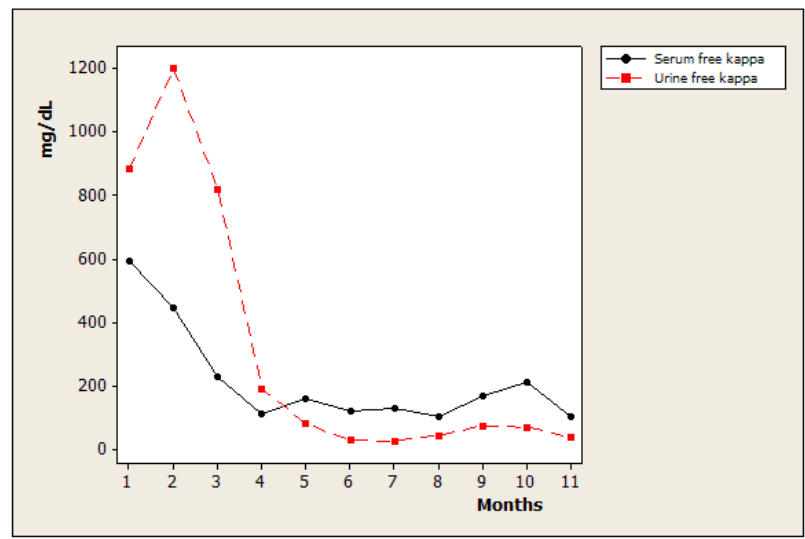

C

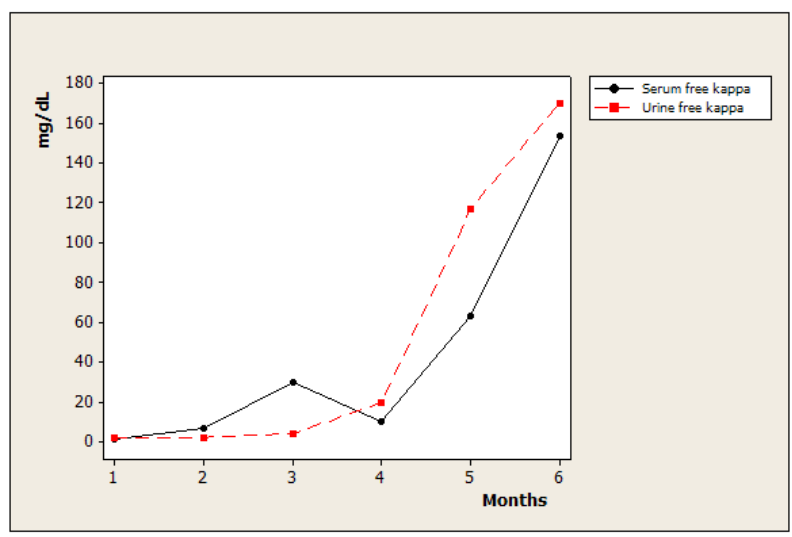

B

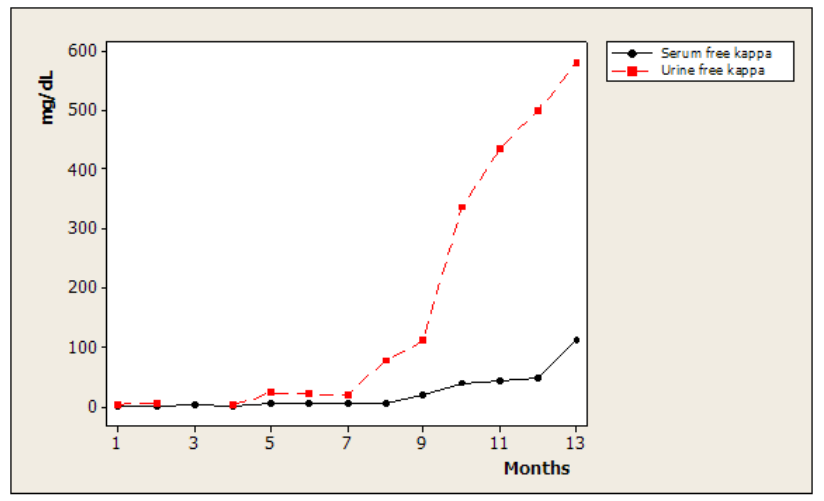

$\mathrm{D}$

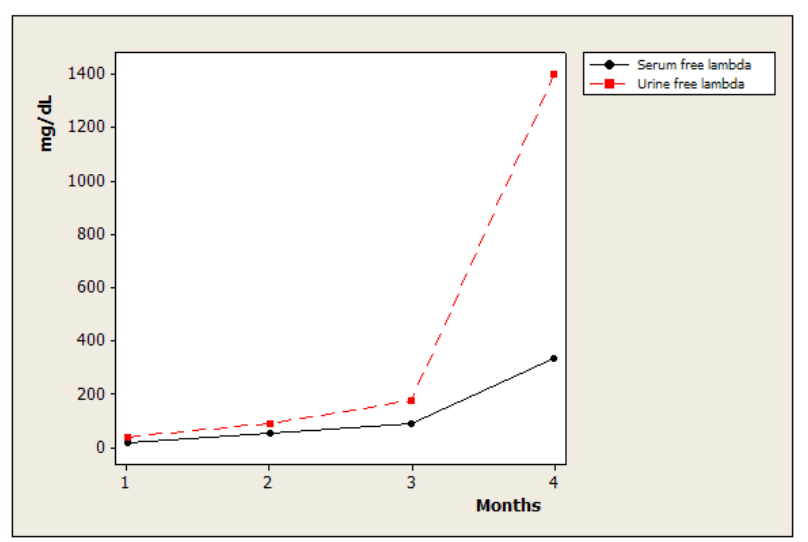

$\mathrm{E}$

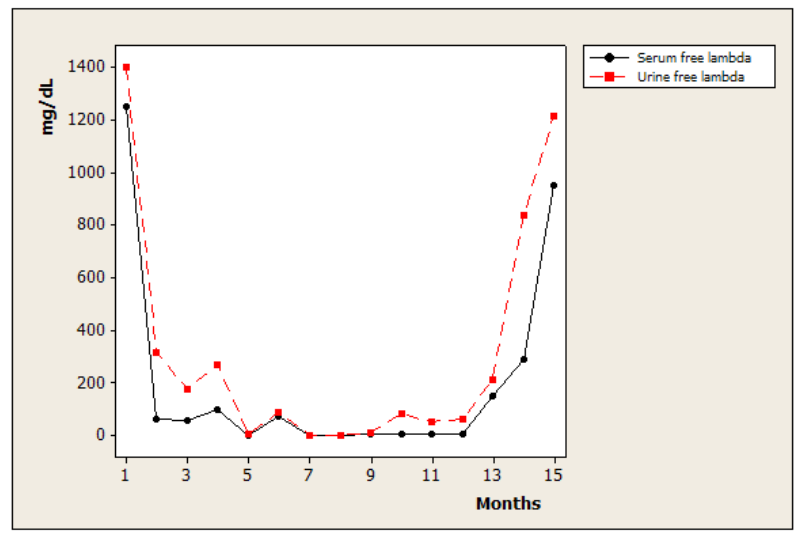

Figure 3. Quantitative free light chain levels in serum and random urine of 5 representative patients, indicating disease remission after therapy (patient A), disease progression (patients B, C, D), and remission followed by progression (patient E)

In our study, we conducted a multivariate analysis which included GFR as a reflection of renal function, because it has been reported that serum kappa and lambda FLC concentrations increase with chronic renal insufficiency and correlate with markers of renal dysfunction ${ }^{[25]}$. This is relevant, as many MM patients develop renal insufficiency during the course 
of their disease. Excessive production of FLCs by the neoplastic plasma cells overwhelms the reabsorption mechanisms of the kidney, with consequent increase of their urinary levels, as damaged nephrons allow greater escape of FLCs into the urine. In our study, patients with renal insufficiency have significantly higher kappa and lambda levels in urine than patients with normal renal function (see Table 1-2), but the correlation between random urine and serum FLCs remained strong even in patients with impaired renal function.

Table 1-1. Multivariate regression analysis

\begin{tabular}{lll}
\hline & Urine FLC (к) & Urine FLC $(\lambda)$ \\
\hline Serum FLC $(\kappa$ or $\lambda)$ & $P<0.0001$ & $P<0.0001$ \\
GFR & $P=0.0114$ & $P=0.0073$ \\
\hline
\end{tabular}

Table 1-2. Comparison of serum and urine FLCs between patients with normal renal function and patients with renal insufficiency

\begin{tabular}{llll}
\hline Mean (SD) & Patients with GFR $>\mathbf{6 0}$ & Patients with GFR $\leq \mathbf{6 0}$ & $\boldsymbol{P}$-value \\
\hline $\log$ Serum $\kappa$ & $0.28(1.95)$ & $1.89(2.27)$ & $<0.0001$ \\
$\log$ Serum $\lambda$ & $0.11(1.90)$ & $1.04(2.53)$ & 0.0105 \\
$\log$ Urine $\kappa$ & $3.71(2.12)$ & $5.66(2.05)$ & $<0.0001$ \\
$\log$ Urine $\lambda$ & $1.32(2.42)$ & $3.16(2.46)$ & 0.0001 \\
\hline
\end{tabular}

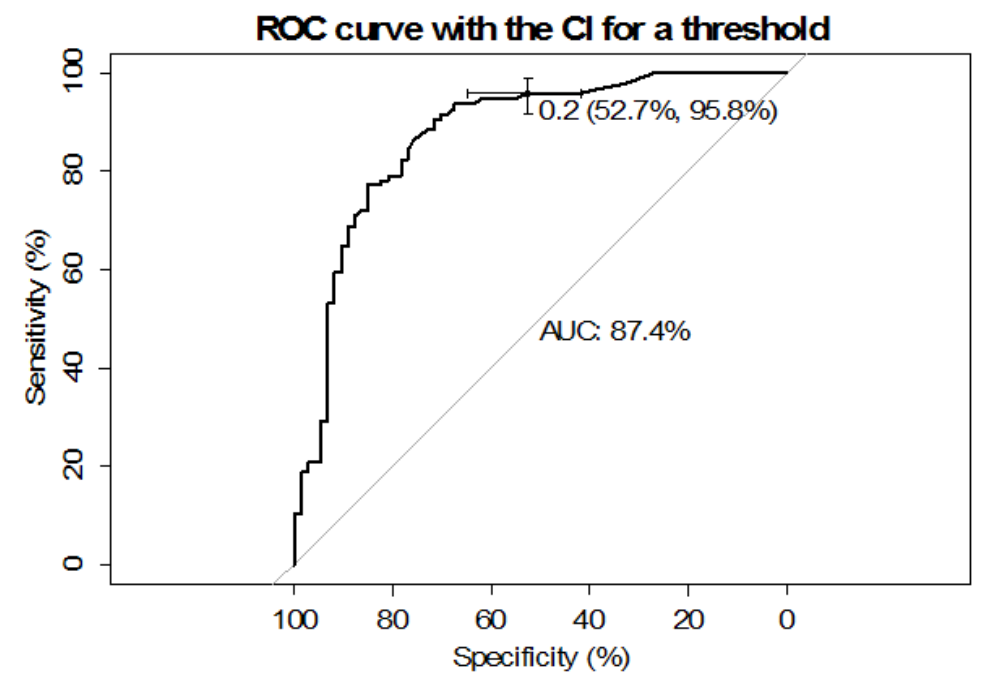

Figure 4. Receiver operating characteristic (ROC) curve generated to show the performance of random urine kappa and lambda FLCs as a binary classifier for the uIFE

The urine FLC threshold of 0.2 on log-scale, which corresponds to $1.2 \mathrm{mg} / \mathrm{dL}$, leads to a specificity and sensitivity of $52.7 \%$ and $95.8 \%$, respectively. The specificity is not high, because the urine FLC levels between uIFE-positive and uIFE-negative patients are not perfectly well-separated. Even though the mean uFLC values are significantly different between these two groups $(p<0.0001)$, optimal sensitivity and specificity cannot be reached simultaneously. Clinically, we believe that reaching high sensitivity (i.e., patients with higher than threshold uFLC levels are uIFE-positive) is more important than reaching high specificity (i.e., patients who are uIFE-negative have lower than threshold uFLC levels). We chose 0.2 as the threshold, because it is the best value which provides $>95 \%$ sensitivity but still maintains a decent $(>50 \%)$ specificity. 
In conclusion, our study evaluated the correlation between serum and random urine FLC levels. Although we do not recommend the routine use of FLC measurement in random urine samples for the routine follow-up and assessment of response to therapy in patients with MM due to the retrospective nature of our study, we should at least recognize that this test has the potential to become an additional tumor marker for patients with MM.

\section{Acknowledgements}

The authors thank Ms. Ginny Hand and Mrs. Lawrie Romberger for assistance in preparation of this manuscript.

\section{Conflict of interest statement}

The authors declare no potential conflict of interest.

\section{References}

[1] Jurisic V, Colovic M. Correlation of sera TNF-alpha with percentage of bone marrow plasma cells, LDH, beta2-microglobulin, and clinical stage in multiple myeloma. Med Oncol. 2002; 19(3):133-9. http://dx.doi.org/10.1385/MO:19:3:133

[2] Jurisic V, Srdic T, Konjevic G, Markovic O, Colovic M. Clinical stage-depending decrease of NK cell activity in multiple myeloma patients. Med Oncol. 2007; 24(3):312-7. PMid:17873307 http://dx.doi.org/10.1007/s12032-007-0007-y

[3] Kyle RA, Gertz MA, Witzig TE, et al. Review of 1027 patients with newly diagnosed multiple myeloma. Mayo Clin Proc. 2003; 78(1):21-33. PMid:12528874 http://dx.doi.org/10.4065/78.1.21

[4] Durie BG, Harousseau JL, Miguel JS, et al. International uniform response criteria for multiple myeloma. Leukemia. 2006; 20(9):1467-73. PMid:16855634 http://dx.doi.org/10.1038/sj.leu.2404284

[5] Kang SY, Suh JT, Lee HJ, Yoon HJ, Lee WI. Clinical usefulness of free light chain concentration as a tumor marker in multiple myeloma. Ann Hematol. 2005; 84(9):588-93. PMid:15883850 http://dx.doi.org/10.1007/s00277-005-1047-z

[6] Abraham RS, Clark RJ, Bryant SC, et al. Correlation of serum immunoglobulin free light chain quantification with urinary Bence Jones protein in light chain myeloma. Clin Chem. 2002; 48(4):655-7. PMid:11901068

[7] Leleu X, Xie W, Bagshaw M, et al. The role of serum immunoglobulin free light chain in response and progression in waldenstrom macroglobulinemia. Clin Cancer Res. 2011; 17(9):3013-8. PMid:21415221 http://dx.doi.org/10.1158/1078-0432.CCR-10-2954

[8] Rao M, Lamont JL, Chan J, et al. Plasma Cell Dyscrasias: Future Research Needs: Identification of Future Research Needs From Comparative Effectiveness Review No. 73. 2012.

[9] Pratt G. The evolving use of serum free light chain assays in haematology. Br J Haematol. 2008; 141(4):413-22. PMid:18318757 http://dx.doi.org/10.1111/j.1365-2141.2008.07079.x

[10] Mead GP, Carr-Smith HD, Drayson MT, Morgan GJ, Child JA, Bradwell AR. Serum free light chains for monitoring multiple myeloma. Br J Haematol. 2004; 126(3):348-54. PMid:15257706 http://dx.doi.org/10.1111/j.1365-2141.2004.05045.x

[11] Dispenzieri A, Kyle R, Merlini G, et al. International Myeloma Working Group guidelines for serum-free light chain analysis in multiple myeloma and related disorders. Leukemia. 2009; 23(2):215-24. PMid:19020545 http://dx.doi.org/10.1038/leu.2008.307

[12] Le Bricon T, Bengoufa D, Benlakehal M, Bousquet B, Erlich D. Urinary free light chain analysis by the Freelite immunoassay: a preliminary study in multiple myeloma. Clin Biochem. 2002; 35(7):565-7. http://dx.doi.org/10.1016/S0009-9120(02)00386-7

[13] Abadie JM, van Hoeven KH, Wells JM. Are renal reference intervals required when screening for plasma cell disorders with serum free light chains and serum protein electrophoresis? Am J Clin Pathol. 2009; 131(2):166-71. PMid:19141376 http://dx.doi.org/10.1309/AJCPR2M4EUYNHLGM

[14] Levey AS, Bosch JP, Lewis JB, Greene T, Rogers N, Roth D. A more accurate method to estimate glomerular filtration rate from serum creatinine: a new prediction equation. Modification of Diet in Renal Disease Study Group. Ann Intern Med. 1999; 130(6):461-70. PMid:10075613 http://dx.doi.org/10.7326/0003-4819-130-6-199903160-00002

[15] Chitalia VC, Kothari J, Wells EJ, et al. Cost-benefit analysis and prediction of 24-hour proteinuria from the spot urine protein-creatinine ratio. Clin Nephrol. 2001; 55(6):436-47. PMid:11434354

[16] Mitchell SC, Sheldon TA, Shaw AB. Quantification of proteinuria: a re-evaluation of the protein/creatinine ratio for elderly subjects. Age Ageing. 1993; 22(6):443-9. PMid:8310890 http://dx.doi.org/10.1093/ageing/22.6.443

[17] Leung YY, Szeto CC, Tam LS, et al. Urine protein-to-creatinine ratio in an untimed urine collection is a reliable measure of proteinuria in lupus nephritis. Rheumatology (Oxford). 2007; 46(4):649-52. PMid:17065189

http://dx.doi.org/10.1093/rheumatology/kel360 
[18] Ginsberg JM, Chang BS, Matarese RA, Garella S. Use of single voided urine samples to estimate quantitative proteinuria. N Engl J Med. 1983; 309(25):1543-6. PMid:6656849 http://dx.doi.org/10.1056/NEJM198312223092503

[19] Austin HA. Clinical evaluation and monitoring of lupus kidney disease. Lupus. 1998; 7(9):618-21. PMid:9884099 http://dx.doi.org/10.1191/096120398678920749

[20] Shaw AB, Risdon P, Lewis-Jackson JD. Protein creatinine index and Albustix in assessment of proteinuria. Br Med J (Clin Res Ed.) 1983; 287(6397):929-32. http://dx.doi.org/10.1136/bmj.287.6397.929

[21] Ruggenenti P, Gaspari F, Perna A, Remuzzi G. Cross sectional longitudinal study of spot morning urine protein:creatinine ratio, 24 hour urine protein excretion rate, glomerular filtration rate, and end stage renal failure in chronic renal disease in patients without diabetes. BMJ. 1998; 316(7130):504-9. PMid:9501711 http://dx.doi.org/10.1136/bmj.316.7130.504

[22] Boler L, Zbella EA, Gleicher N. Quantitation of proteinuria in pregnancy by the use of single voided urine samples. Obstet Gynecol. 1987; 70(1):99-100. PMid:3601274

[23] Wozney JL, Damluji AA, Ahmed F, Zangari M, Loughran TP, Jr., Talamo G. Estimation of daily proteinuria in patients with multiple myeloma by using the protein-to-creatinine ratio in random urine samples. Acta Haematol. 2010; 123(4):226-9. PMid:20424436 http://dx.doi.org/10.1159/000313448

[24] Alyanakian MA, Abbas A, Delarue R, Arnulf B, Aucouturier P. Free immunoglobulin light-chain serum levels in the follow-up of patients with monoclonal gammopathies: correlation with 24-hr urinary light-chain excretion. Am J Hematol. 2004; 75(4):246-8. PMid:15054820 http://dx.doi.org/10.1002/ajh.20007

[25] Hutchison CA, Harding S, Hewins P, et al. Quantitative assessment of serum and urinary polyclonal free light chains in patients with chronic kidney disease. Clin J Am Soc Nephrol. 2008; 3(6):1684-90. PMid:18945993

http://dx.doi.org/10.2215/CJN.02290508 